\title{
ORIGINAL ARTICLE \\ Bats from the understorey of lowland tropical rainforests across Peninsular Malaysia
}

\author{
Lee-Sim Lim ${ }^{1,2, *, * *}$, Matthew J. Struebig ${ }^{3, * *}$, Mohamed Nor Zalipah4 ${ }^{4}$, Adura Mohd-Adnan ${ }^{5}$, Juliana \\ Senawi ${ }^{6}$, Akbar Zubaid $^{7}$, Shahrul Anuar Mohd Sah ${ }^{8}$, Stephen J. Rossiter ${ }^{1}$
}

${ }^{1}$ School of Biological and Chemical

London, London E1 4NS, UK

${ }^{2}$ School of Distance Education, Universiti Sains Malaysia, 11800, Penang, Malaysia

${ }^{3}$ Durrell Institute of Conservation and Ecology, School of Anthropology and Conservation, University of Kent, Canterbury CT2 7NR, UK

${ }^{4}$ Faculty of Science and Marine Environmental Sciences, Universiti Malaysia Terengganu, 21030, Kuala Nerus, Terengganu, Malaysia

${ }^{5}$ School of Biosciences and

Biotechnology, Faculty of Science and

Technology, Universiti Kebangsaan

Malaysia, 43600 Bangi, Selangor,

Malaysia

${ }^{6}$ Institute for Environment and

Development, Universiti Kebangsaan

Malaysia, 43600 Bangi, Selangor

Malaysia

${ }^{7}$ School of Environmental Science and Natural Resources, Faculty of Science

and Technology, Universiti Kebangsaan

Malaysia, 43600 Bangi, Selangor, Malaysia

${ }^{8}$ School of Biological Sciences, Universiti Sains Malaysia, 11800, Penang, Malaysia

${ }^{* *}$ These authors were contributed equally as the role of first author

*Corresponding author: leesim.lim@usm.my

DOI: https://doi.org/10.14709/BarbJ.12.1.2019.10

Keywords: conservation, Kelawar, lowland evergreen, Peninsular Malaysia, tropical rainforest

received: October, 10th 2019

accepted: December, 3rd 2019

\begin{abstract}
To date, 110 bat species are recorded in Peninsular Malaysia. Many of these species depend upon tropical forests, which have rapidly decreased in extent over recent decades. Yet, updated information on species distributions in the region is still lacking. Here, we report bat species records and their distribution based from surveys undertaken at $\mathbf{3 0}$ lowland tropical rainforest sites across Peninsular Malaysia. We recorded 56 species from seven families. The three most abundant species across the peninsula were Rhinolophus affinis, Hipposideros bicolor complex and Hipposideros cervinus. Four out of nine singleton species (Chironax melanocephalus, Coelops robinsoni, Myotis hermani and Hesperoptenus doriae) are forest specialists that are patchily distributed across the peninsula, while another five are open space/edge species that utilise the forest occasionally. The understorey assemblage comprises frugivorous, insectivorous and nectar-drinking species. Thirteen percent of all captured species are represented by at least one record outside of their previous known distributional range. Furthermore, our study suggests that updated and informative species distribution is essential to further study these bat species since information on their ecology and basic natural history remains poorly known. An improved understanding of species ecology and population status will contribute to more effective conservation efforts. Our survey data provide comprehensive records of understorey forest bats in a biodiversity hotspot.
\end{abstract}

\section{INTRODUCTION}

The Malaysian peninsula is the southernmost part of the Asia mainland, located in the centre of the Sunda Shelf (Fig. 1). It forms part of the Sundaland biodiversity hotspot and is a global conservation priority (Cincotta et al. 2000, Myers et al. 2000, Williams 2013). Kuala Lompat from the central region of Peninsular Malaysia hosts the largest concentration of bat richness than any single site surveyed in the Old World tropics to date (Kingston et al. 2003). This impressive bat fauna contributes to the maintenance of healthy and balanced ecosystems and the economy of the country. For example, fruit- and nectar-feeding bats (family Pteropodidae) serve as seed dispersers and pollinators of many economically important plant species, such as the durian, banana and bitter beans, increasing quantity and quality of these crops (Marshall 1983, Fujita \& Tuttle 1991, Shilton et al. 1999, Hodgkison et al. 2003, Kingston et al. 2006, Kunz et al. 2011, Aziz et al. 2017, Chaiyarat et al. 2019, Sheherazade et al. 2019). In addition, insectivorous bats are known to serve as effective natural pest control agents in the region (Kingston et al. 2006, Kunz et al. 2011, Wanger et al. 2014).

The long term viability of many forest-dependent bat species in Peninsular Malaysia is uncertain due to substantial habitat loss (Lim et al. 2014, Keenan et al. 2015). Malaysia has lost $1.6 \%$ of its natural forest between the year 2010 
and 2017 (Hansen et al. 2019) for massive and unsustainable development (Tan-Soo et al. 2016, Global Forest Watch 2019). This resulted in widespread forest degradation and fragmentation, leaving only $15 \%$ of land as primary forest (FAO 2019). Studies on bat diversity in Peninsular Malaysia demonstrate how bat community composition varies latitudinally, as well as being affected by habitat area (Struebig et al. 2008, Lim et al. 2014). Richness is higher towards the south, and in forest blocks $>300$ ha in size. Thus, it is important to maintain large and continuous tracks of natural forest across the southern-most peninsula of Asia Continent.

The dominant insectivorous bat groups in insular Southeast Asia (e.g. Hipposideridae, Rhinolophidae, Murininae, and Kerivoulinae) have evolved over millennia to live within highly-dense humid tropical forests and are thus ill-equipped to adapt to rapid changes in forest structure and cover (Kingston et al. 2003). The anthropogenic consequences on bat diversity were reflected by neighbouring Singapore. The island experienced massive development since the 1960s, which led to the extirpation of one-third of the country's bat fauna (Lane et al. 2006). Nevertheless, subsequent bat surveys in Singapore have reported two microchiropteran species as new records and rediscovered $H$. bicolor on the island (Chan et al. 2009, Leong \& Lim 2009), demonstrating the values of regular surveys and monitoring.

Bat research in Peninsular Malaysia began in the mid19th century (Wallace 1860, Anon 1900) following the arrival of British colonialists. Since then, the number of species observed in the country has increased, and numerous taxonomic revisions were conducted during the twentieth century (e.g. Chasen 1936, 1940, Muul \& Liat 1971, Stiller 1976, Mialhe \& Landau 1977, Lim \& Muul 1978, Gould 1978a, 1978b). Research effort further escalated in 2001 after the establishment of the Malaysian Bat Conservation and Research Unit, a platform and network to bring bat researchers in the country and international bat experts together (Kingston et al. 2012).

Despite intensive bat research over the last two decades, there was no comprehensive inventory on bat diversity across Peninsular Malaysia after Corbet \& Hill (1992). We aim to fill this gap by reporting on a four-year intensive forest understorey survey campaign of lowland rainforest sites across the Peninsular Malaysia. We provide descriptions for each bat species reported, in terms of recorded localities and patchiness for species' distribution across Peninsular Malaysia. This information is an important guide for bat conservation and monitoring programs in Malaysia and neighbouring Southeast Asian countries.

\section{MATERIALS AND METHODS}

\section{Study Site}

We performed bat surveys in 30 sites in lowland mixed dipterocarp evergreen tropical rainforest across Peninsular Malaysia (Table 1, Fig. 1). Fieldwork was conducted between January and October from 2007 to 2010. All survey sites were lowland (<300 m.a.s.l.) intact forest reserves of

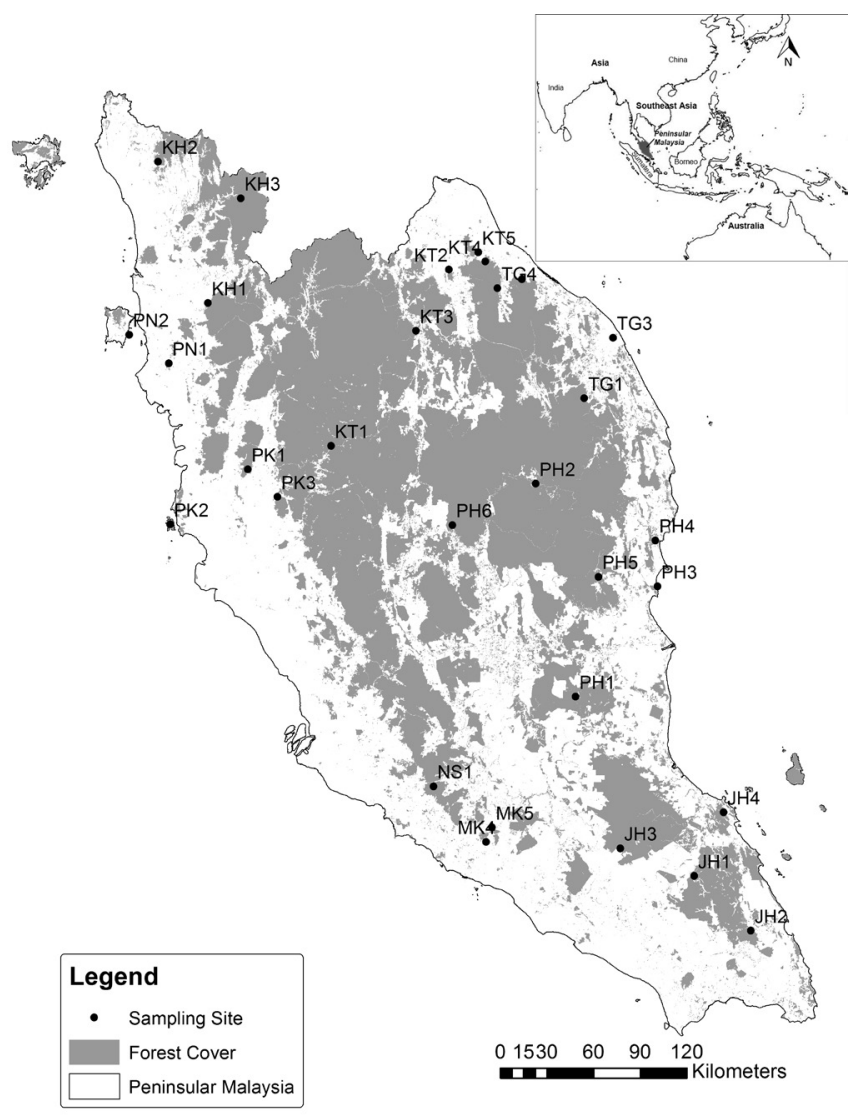

Fig. 1 - Map of Peninsular Malaysia showing the 30 lowland tropical rainforest sites visited in this study; Inset: location of Peninsular Malaysia in Southeast Asia and the wider region.

more than 1000 ha and were recovering from past logging activities undertaken in the previous 30 years. These forest reserves are protected, monitored and enforced by Forestry Department Peninsular Malaysia.

\section{Bat capture and species identification}

Surveys were conducted to primarily target insectivorous bats using harp traps, but netting was also deployed on occasions (Table 1). Depending on access, between two and eight four-bank harp traps were placed across forest trails, old logging skids or small streams. Traps were set at 19:00h and were checked regularly from 20:00h to 22:00h and again at 07:00h the following morning. In some sites where harp trapping was difficult, hand nets and mist nets were used. Hand nets were used when sampling bats from small boulders and caves in the forest sites while two to four four-shelf nets were deployed in forest areas with less understorey vegetation each trapping night, such as along stream banks, or at trapping locations with open mid-storey. We therefore also report some Pteropodid records, which were captured in the mist nets.

To aid in the species identification, standard morphological measurements were taken for each individual such as the length of forearm, tibia, and tail using dial callipers and the body mass using a spring balance. Bats were then identified based on Kingston et al. (2006) and Francis (2008). Wing tissue punches of ca. $3 \mathrm{~mm}$ in diameter were collected from each capture bat prior to release for future examination and confirmation of identity 
for a subset of captures. Voucher specimens were only collected if a bat died during the trapping and processing. Voucher specimens were deposited at the Zoology Museum in Universiti Kebangsaan Malaysia and General Biology Lab in Universiti Malaysia Terengganu.

To provide a clearer comparison of community structure across sites we report the proportional abundance of each bat species (percentage of total catch for the target species over total catch of all species) alongside habitat and landscape characteristics of each site (Table 2). For each species we also report the proportion of sites with at least one capture (Total number of visited sites over number of sites with target bat species)- i.e. the naïve occupancy - as a simple indicator of patchiness within each species distribution across Peninsular Malaysia.

\section{RESULTS}

Throughout the four-year survey period, we captured 3169 individuals of 56 bat species from seven families across the peninsula (Table 2, Fig. 2). This included species from the families pteropodidae, emballonuridae, hipposideridae, rhinolophidae, vespertilionidae, megadermatidae and nycteridae (Fig. 2). Recaptured individuals, identified via the wing tissue biopsies taken for each individual, were excluded from the record and analyses. Of a total of 18 species of Pteropodid bats recorded previously for Peninsular Malaysia, we recorded only eight (44\%) during the study. We recorded 23 vespertilionid, 12 hipposiderid and 10 rhinolophid species (Fig. 2).
Among the bats captured, the most common and abundant species was Rhinolophus affinis (22\% of total captured individuals, $87 \%$ of sites occupied), followed by Hipposideros cf. bicolor $H$. cervinus, $H$. larvatus, $R$. lepidus, Cynopterus brachyotis and Kerivoula papillosa (Table 2). Ten singleton species were captured: Chironax melanocephalus, Coelops robinsoni, Hesperoptenus doriae, Hesperoptenus blanfordi, Kerivoula krauensis, Myotis muricola, M. hermani, Scotophilus kuhlii, Tylonycteris pachypus and T. robustula.

Seven species were reported outside of their known distribution on the Malay peninsula: Hipposideros doriae (approx. $50 \mathrm{~km}$ north of distribution range), Hipposideros dyacorum (approx. $50 \mathrm{~km}$ south), Hipposideros pomona (approx. $350 \mathrm{~km}$ south), Hesperoptenus doriae (approx. $100 \mathrm{~km}$ south), Kerivoula intermedia (approx. $50 \mathrm{~km}$ north), Myotis ater (approx. $100 \mathrm{~km}$ south), and Rhinolophus sedulus (approx. $155 \mathrm{~km}$ north). Meanwhile, we also captured five open-space species in our forest inventories (Miniopterus magnater, Hesperoptenus blanfordi, Scotophilus kuhlii, Tylonycteris pachypus and Tylonycteris robusta).

Among the bat species recorded, nine of the 56 (16\%) species are categorised by the IUCN Red List as 'Near threatened', three as 'Vulnerable', and three as 'Data deficient' (Table 2). Out of 30 sites sampled, $\mathrm{PH} 2\left(102.68^{\circ} \mathrm{E}\right.$, $4.41^{\circ} \mathrm{N}$ ) (Table 1) from the centre of Peninsular Malaysia has the highest number of bat species recorded ( $n=24$ spp.; $43 \%$ of total captured species). This was followed by JH2 ( $n=23$ spp., $41 \%$ of total captured species). Other forest with at least 20 bat species were TG1 (21 species recorded), JH3 (20 species recorded) and KT2 (20 species recorded).

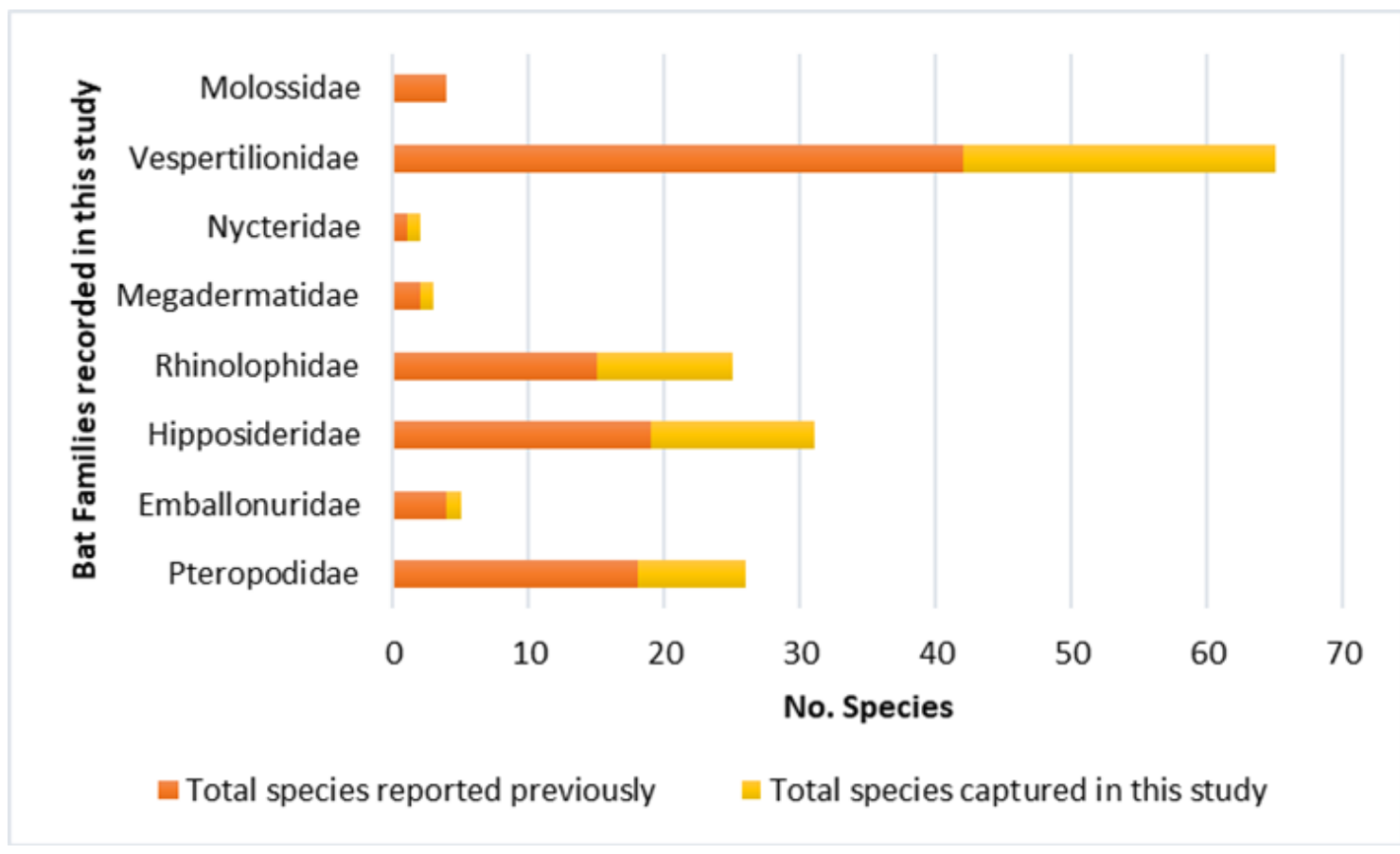

Fig. 2 - The number of species recorded during the 4-year survey campaign compared to the known total bat fauna reported for Peninsular Malaysia.. 


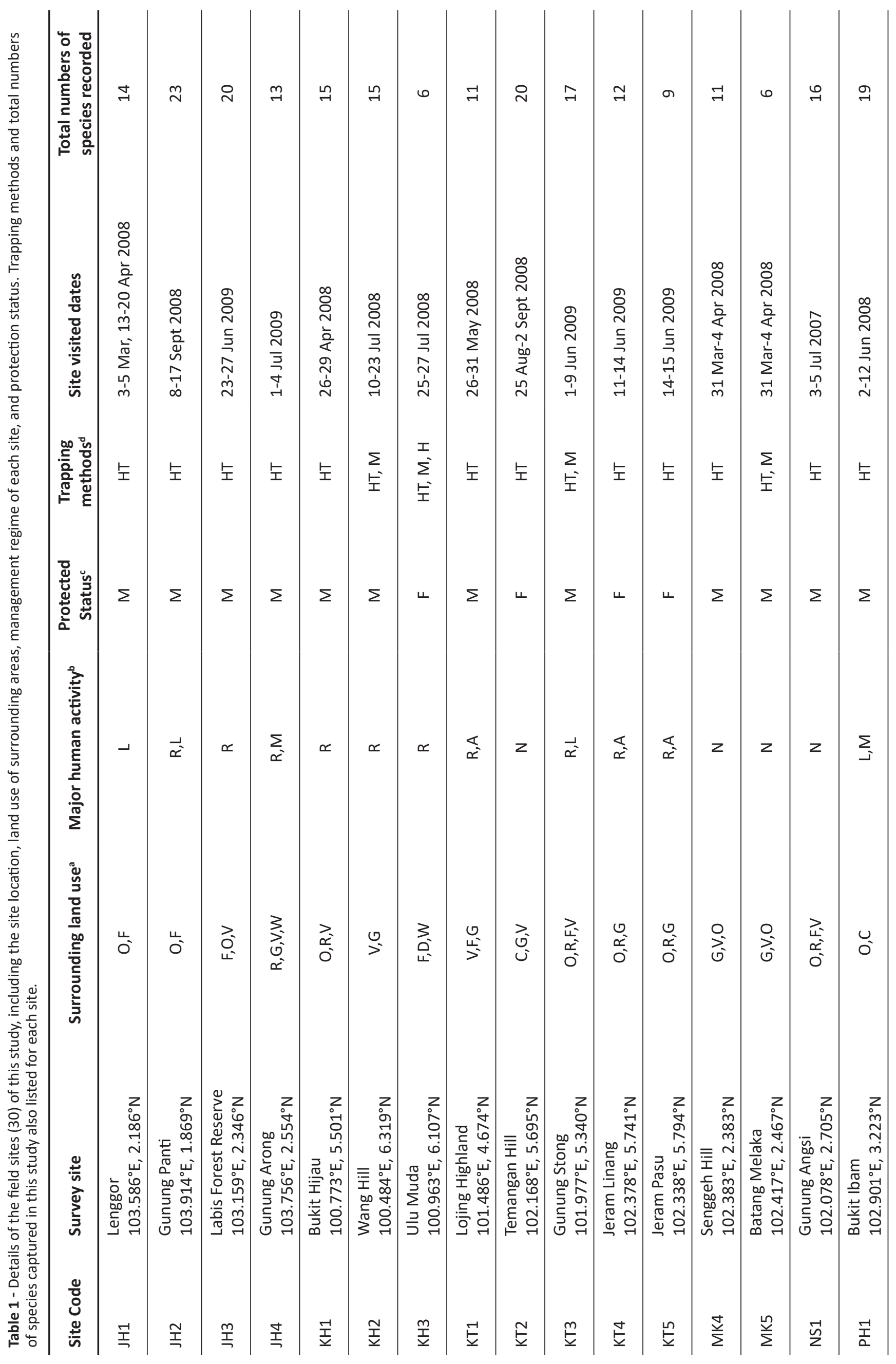




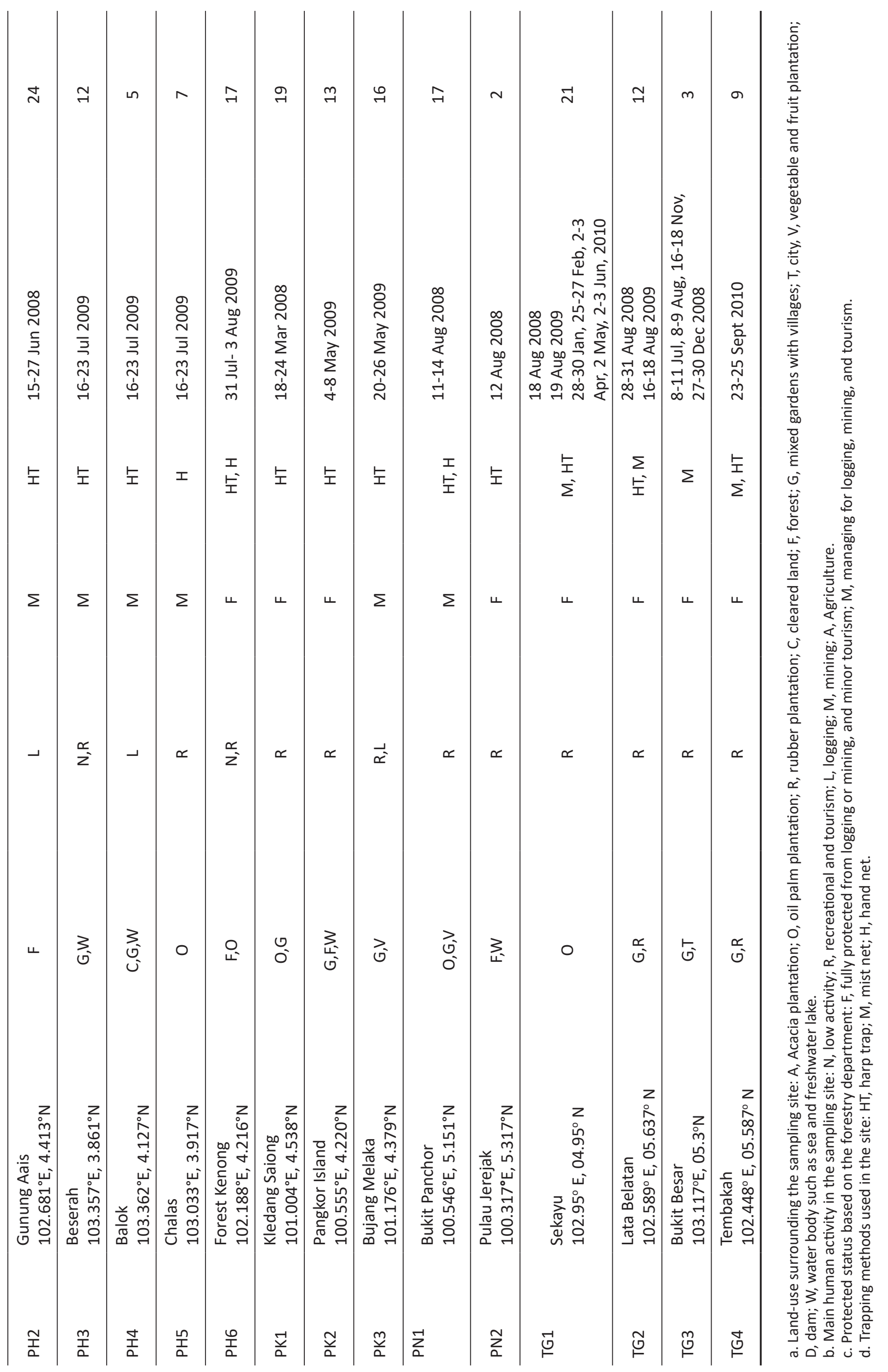




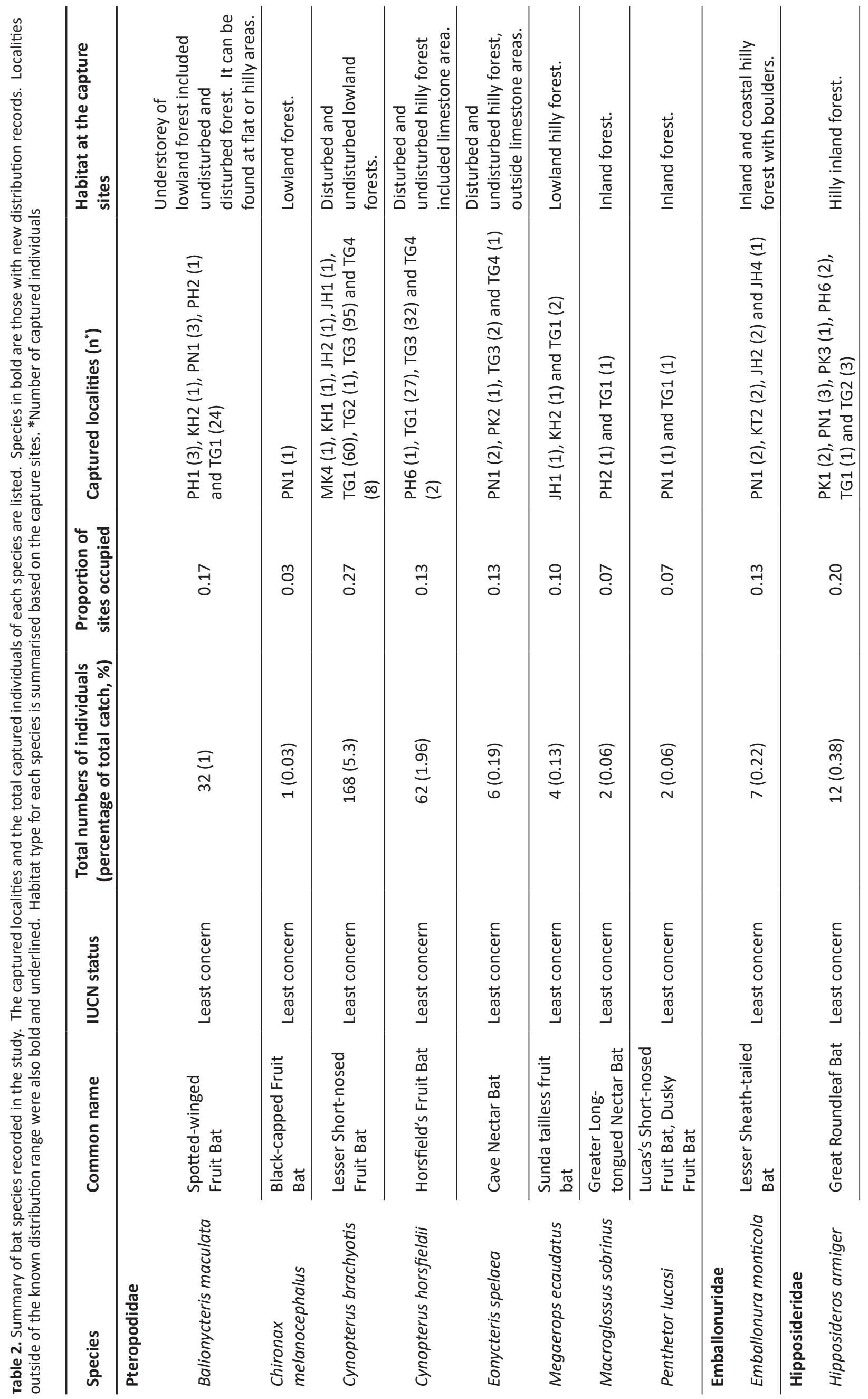




\begin{tabular}{|c|c|c|c|c|c|c|c|c|c|c|}
\hline 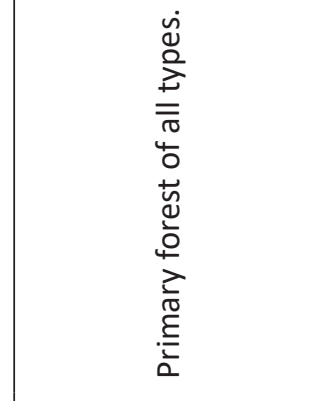 & 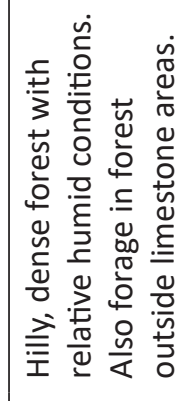 & 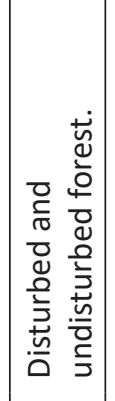 & 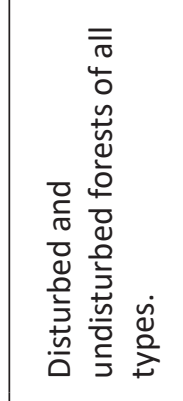 & 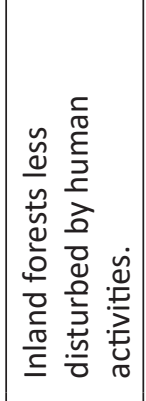 & 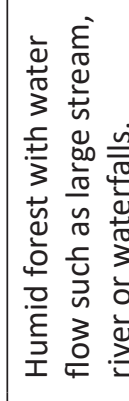 & 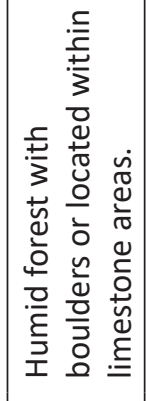 & 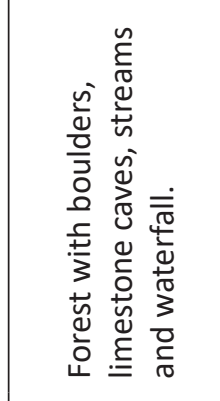 & 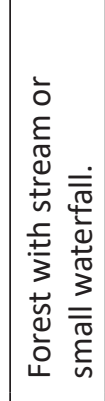 & 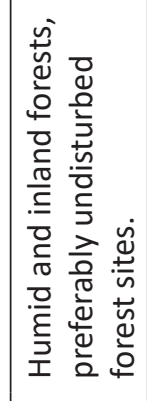 & 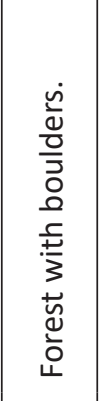 \\
\hline 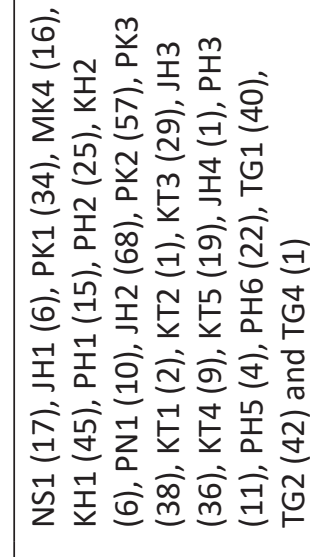 & 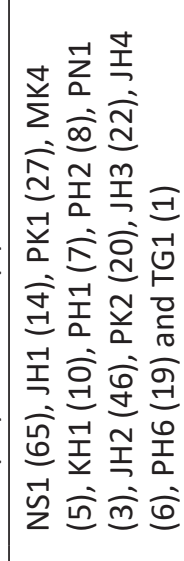 & 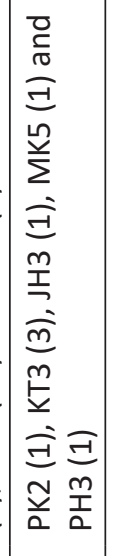 & 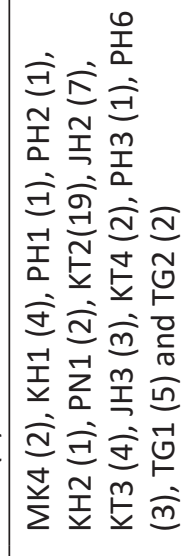 & 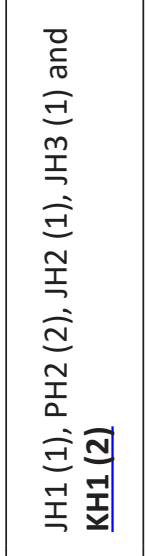 & 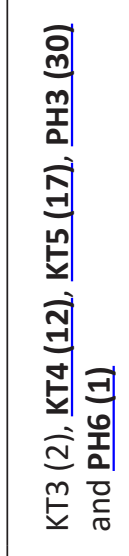 & 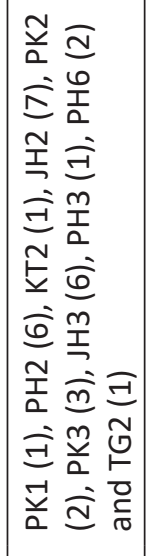 & 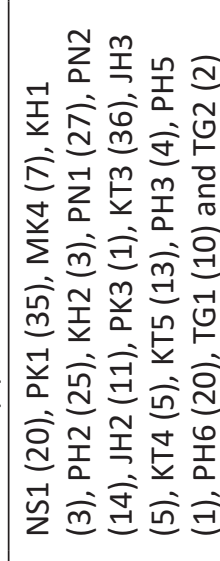 & 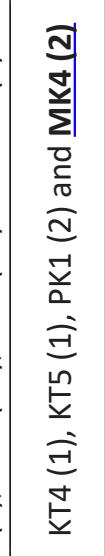 & 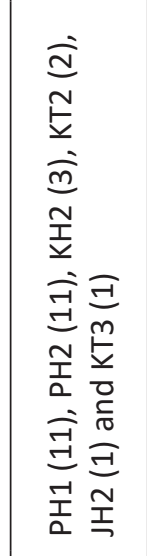 & $\begin{array}{l}\Xi \\
5 \\
上\end{array}$ \\
\hline $\begin{array}{l}\infty \\
\stackrel{\infty}{0} \\
0\end{array}$ & f̊̀ & ને & 员 & ને̊ & ને̊ & $\stackrel{m}{m}$ & $\stackrel{\mathscr{0}}{\circ}$ & $\stackrel{m}{0}$ & ָ̊ & $\begin{array}{l}\text { o } \\
\text { o. }\end{array}$ \\
\hline 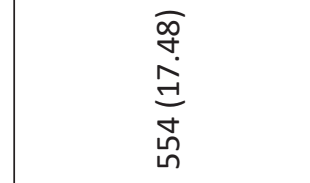 & $\begin{array}{l}\widehat{\widehat{D}} \\
\stackrel{N}{N} \\
\stackrel{D}{\sim}\end{array}$ & $\begin{array}{l}\overline{\mathbb{N}} \\
\stackrel{O}{N}\end{array}$ & $\begin{array}{l}\bar{\infty} \\
\stackrel{\infty}{i} \\
\text { in }\end{array}$ & $\begin{array}{l}\underset{N}{N} \\
\stackrel{D}{N}\end{array}$ & $\begin{array}{l}\bar{o} \\
\stackrel{ه}{-} \\
\widetilde{\sigma}\end{array}$ & $\begin{array}{l}\bar{n} \\
\stackrel{0}{\circ} \\
0 \\
0\end{array}$ & $\begin{array}{l}\text { J্ } \\
\stackrel{D}{~} \\
\mathcal{N}\end{array}$ & $\begin{array}{l}\bar{\sigma} \\
\stackrel{7}{0} \\
0 \\
0\end{array}$ & $\begin{array}{l}\widehat{\widehat{J}} \\
\stackrel{0}{0} \\
\text { న్ }\end{array}$ & \\
\hline 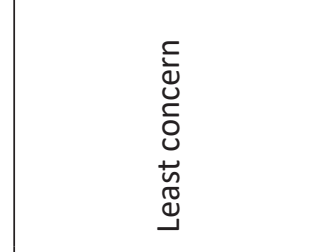 & 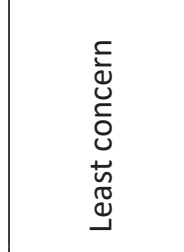 & 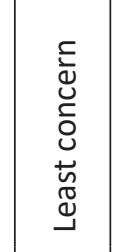 & 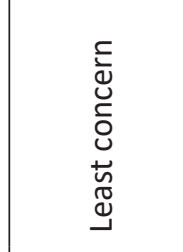 & 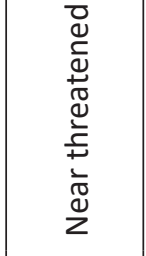 & 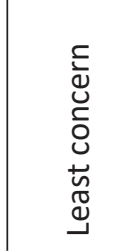 & 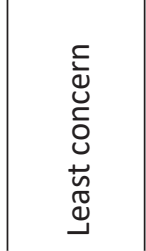 & 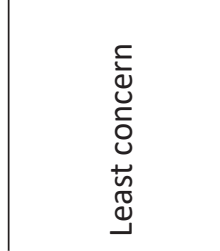 & 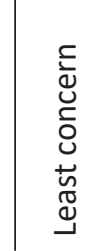 & 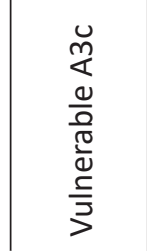 & \\
\hline 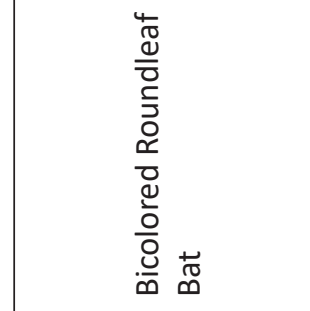 & 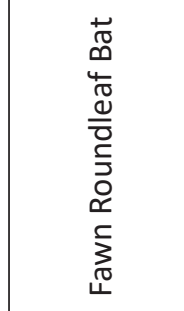 & 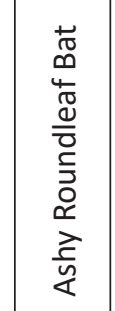 & 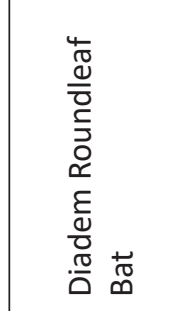 & 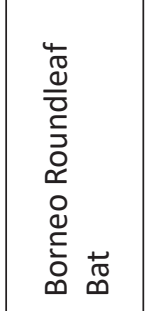 & 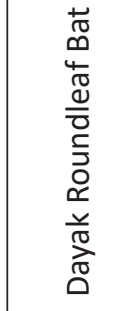 & 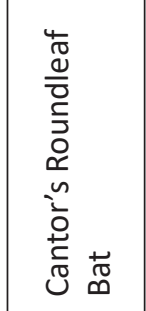 & 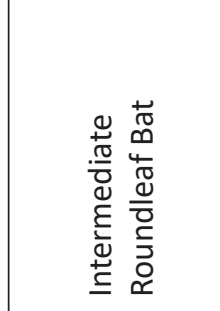 & 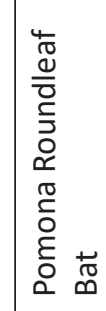 & 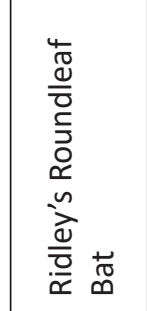 & 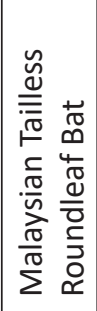 \\
\hline 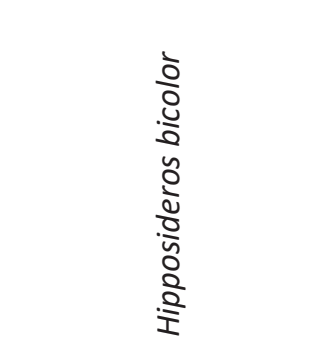 & 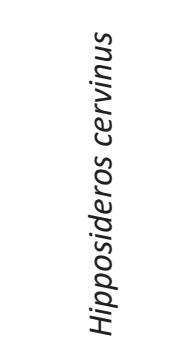 & 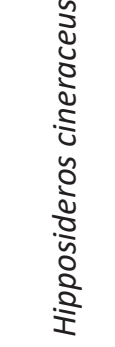 & 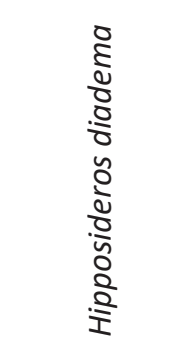 & 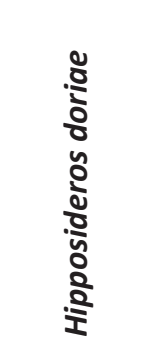 & 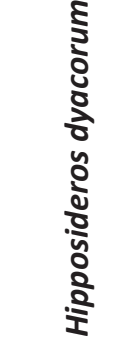 & 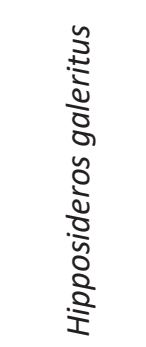 & 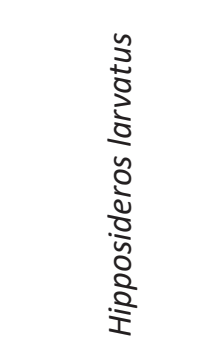 & 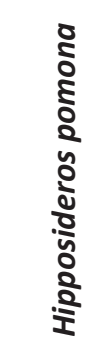 & 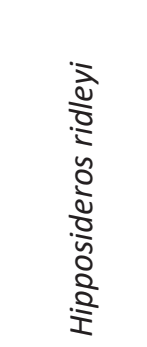 & . \\
\hline
\end{tabular}




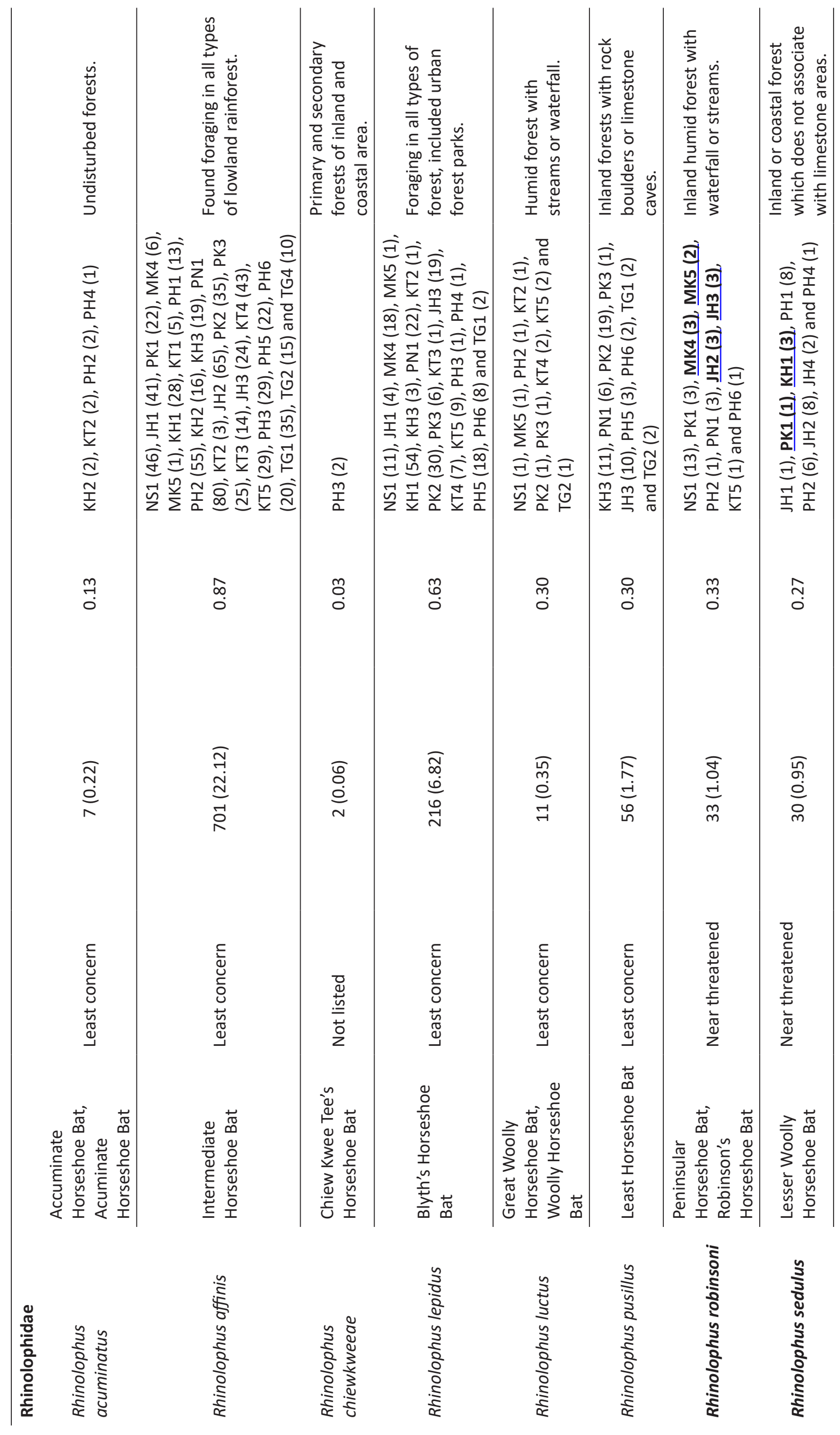




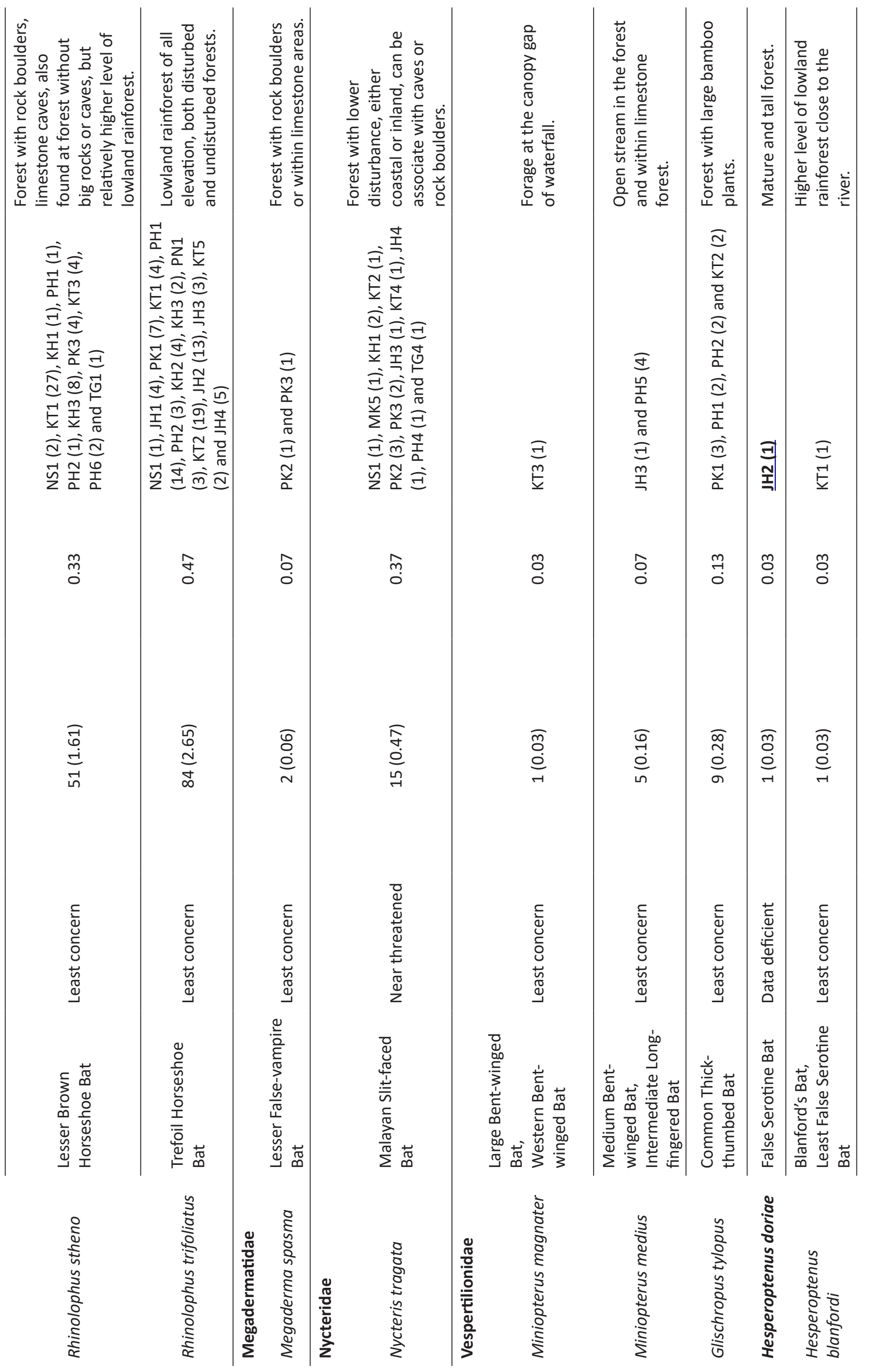




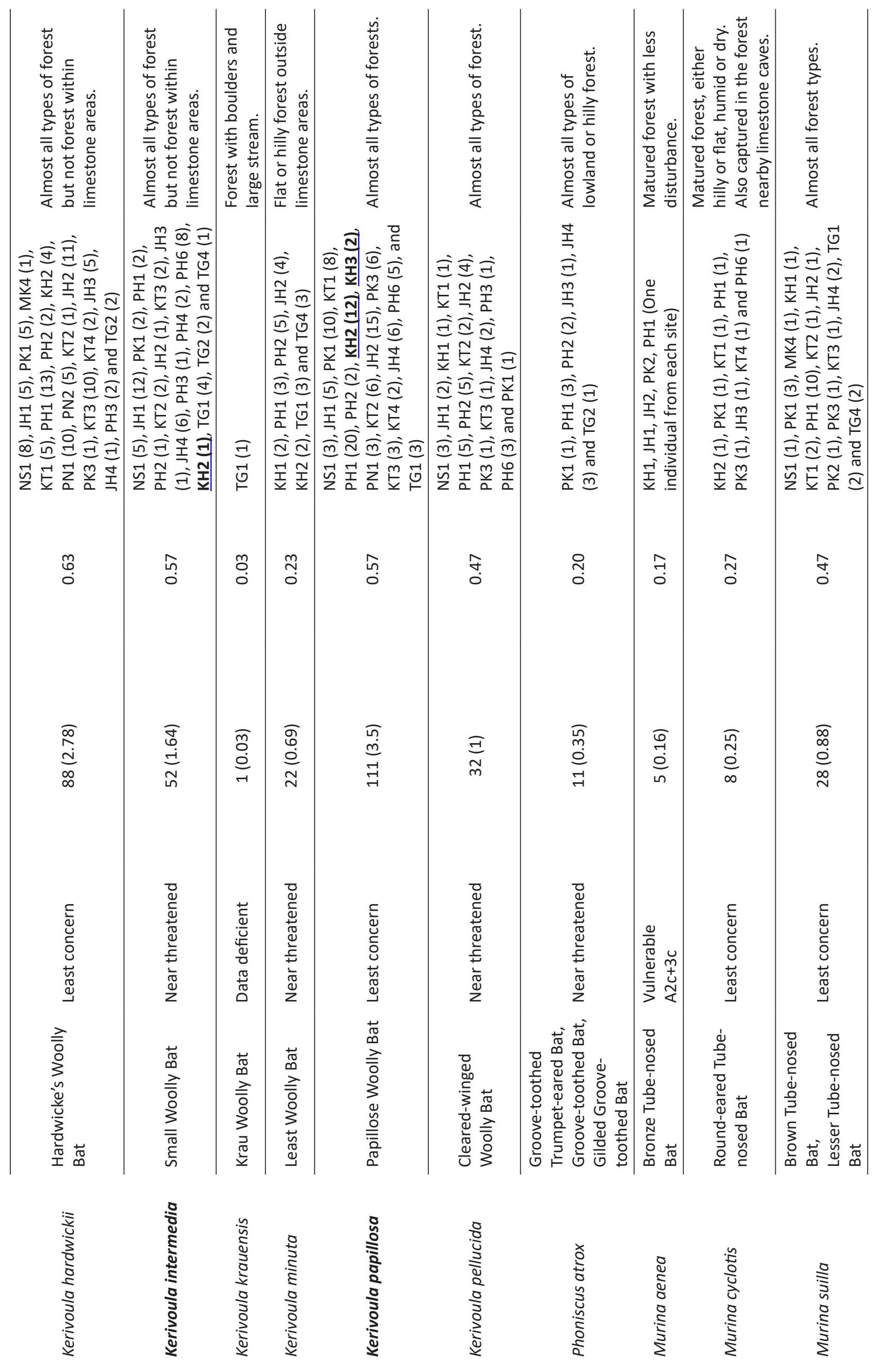




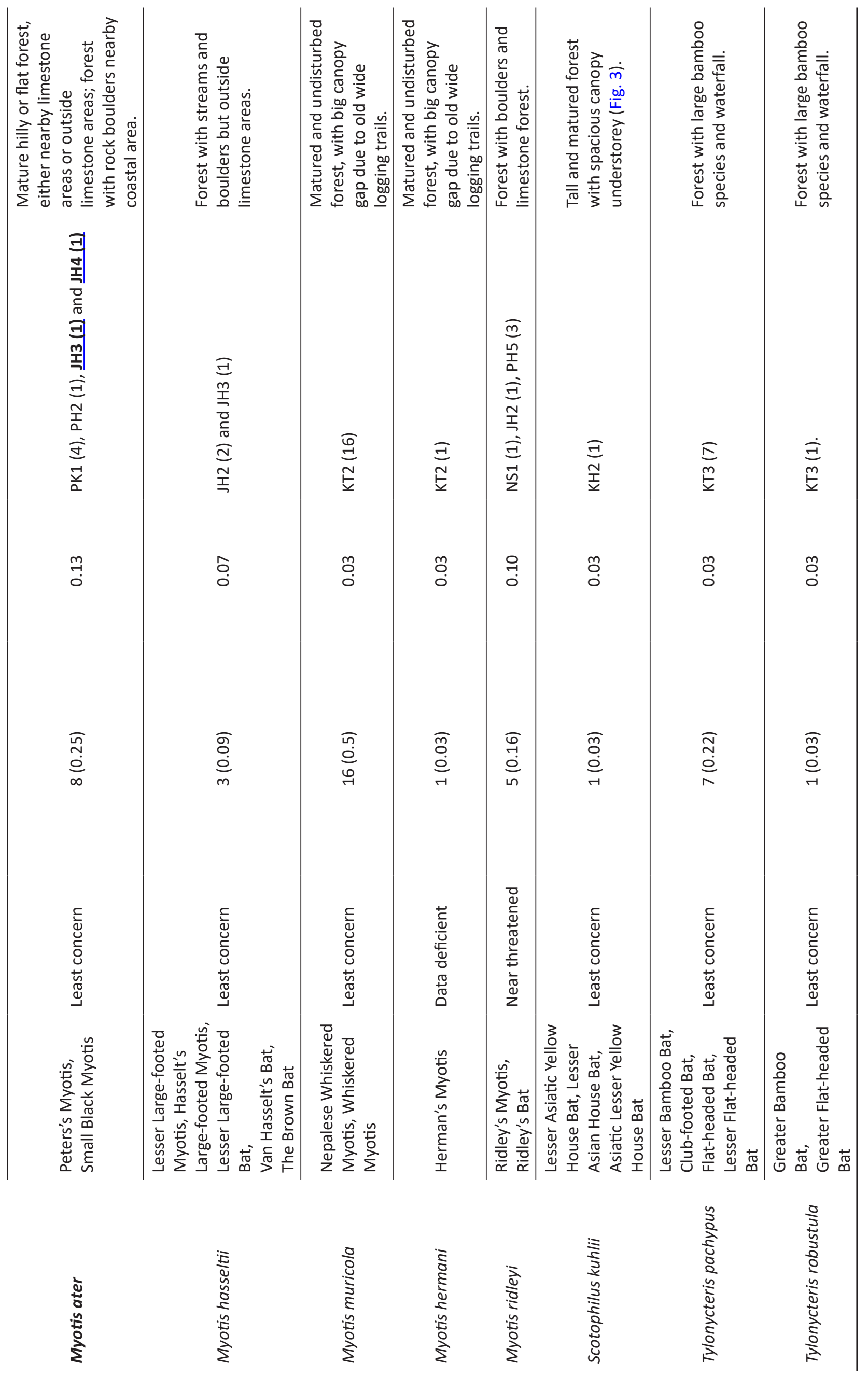




\section{DISCUSSION}

With 110 species representing eight families of bats (Lim et al. 2017), Peninsular Malaysia hosts the highest density of Old World bat species (i.e., total number of species reported per total area of land) relative to other geopolitical territories within Southeast Asia. There have been several studies conducted to understand the biology of some of these bats in the past, such as the roosting behaviour of two Tylonycteris species (Medway \& Marshall 1972) and comparison on the morphological niche and community structure of insectivorous bats from Palaeotropics with those from Neotropics (Heller \& Volleth 1995). However, the biology and ecology of most of these species remain understudied (Meyer et al. 2016).

The three most abundant forest species in our survey ( $R$. affinis, $H$. bicolor complex, $H$. cervinus) are known to roost primarily in caves (Kingston et al. 2006, Francis 2008) but our data clearly demonstrate they dominate bat communities in nearby forests (Table 2). Although some species such as $R$. affinis and $R$. lepidus are considered to be narrow-space foragers, research in central Peninsular Malaysia demonstrated they can travel between foraging sites (Struebig et al. 2009). The short and broad wings of these species equip them for flying in more cluttered environments (Norberg \& Rayner 1987), and so it is likely that they still require some form of forested landscape features such as forest patches or riparian areas, commute to foraging sites.

In contrast, Miniopterus magnater, Hesperoptenus blanfordi, Scotophilus kuhlii, Tylonycteris pachypus and Tylonycteris robusta were the five singletons categorised as edge or open space species. These insectivorous bat species also have been reported to be common and widely distributed in heavily urbanised areas of the country (Francis
2008, Struebig et al. 2008), but were rarely captured in our forest sites. These species typically fly high and forage above the forest canopy but are sometimes detected in the forest understorey near canopy gaps or when accessing water resources. We captured all the open space singletons at river or waterfall, except Scotophilus kuhlii which was captured at the spacious understorey of tall and matured unlogged rainforest with very little undergrowth vegetation (Fig. 3, Table 2). Scotophilus kuhlii has been found to occasionally roost and forage in the forest and tree plantations too (Kingston et al. 2006, Francis 2008). In comparison to other forest specialist species reported in this study, the edge/ open species we captured already evolved to travel far and survive well in open spaces (Evans 2010), thus face lower risk of extinction from the rapid deforestation cum urbanisation in Peninsular Malaysia.

The forests of Peninsular Malaysia also host bat species that entirely depend on the tropical rainforest in terms of roosting and foraging habitat. Members within the vespertilionid subfamilies Kerivoulinae and Murininae either roost solitary or in small groups, and are not as abundant as the cave roosting bats recorded in the study (Rossiter et al. 2012). This group of species have morphological traits that are adapted to a high-dense tropical forest (Stockwell 2001, Kingston et al. 2003, Hodgkison et al. 2004, Mancina et al. 2012) thus they are sensitive and vulnerable to deforestation and forest degradation (Struebig et al. 2008). Therefore, this group of forest specialists should be prioritised in current bat conservation strategy.

Rhinolophus chiewkweeae is a new species first captured from Gunung Ledang, west-coast of Peninsular Malaysia in 2005 (Mizuko \& Liat 2005) and later discovered from five localities along the west coast as well as one locality at the north east coast of Peninsular Malaysia by Morni et al. (2016). In our study, we captured one male adult and
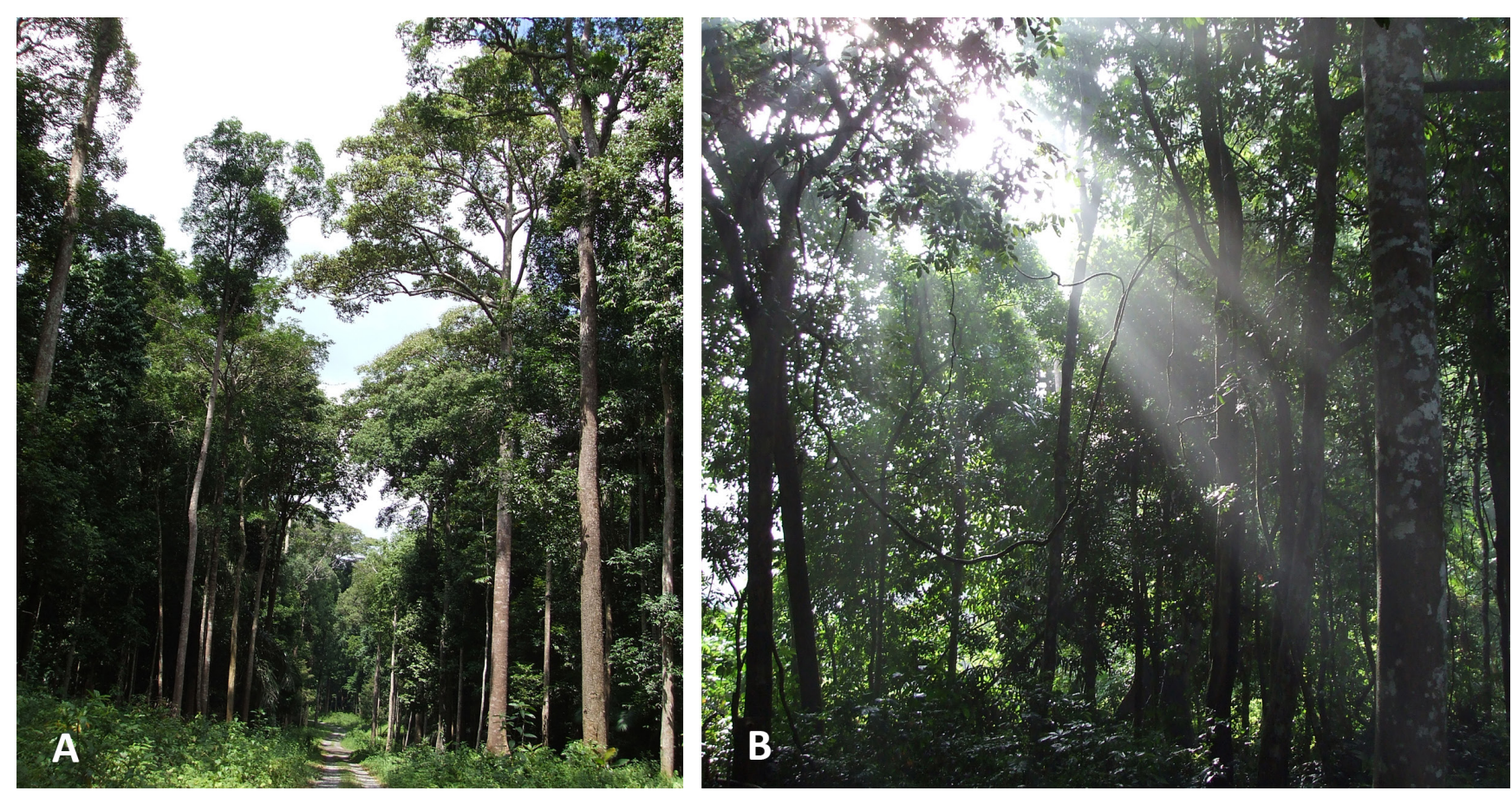

Fig. 3 - The habitat of where the singleton Scotophilus kuhlii was captured: A) the high and thick canopy of the forest viewed from the forest gap; B) the forest interior illuminated by morning sun. Photos were taken by Ching Fong Lau, Perak State Park Corporation. 
one female adult of Rhinolophus chiewkweeae from $\mathrm{PH}$, a forest site within Pahang state of Peninsular Malaysia, making PH3 the second forest site located at the east coast of Peninsular Malaysia reported the existence of Rhinolophus chiewkweeae. The historical distribution of bat species may change over time due to habitat change and climate change (Struebig et al. 2015). However, the new distribution records may be be an artefact of inadequate sampling effort or sampling techniques used in the past. Hence, more comprehensive baseline surveys are still necessary in many parts of the Southeast Asian tropics.

\section{CONCLUSIONS}

This study provides distribution records of understorey forest bats across Peninsular Malaysia at the beginning of the second millennium and reveals new localities outside the known distributional range for seven species. Of 56 reported species, nine were categorised as Near threatened by IUCN Redlist in year 2008 (e.g. Kerivoula minuta, Kerivoula pellucida, Phoniscus atrox, Hipposideros doriae, Hipposideros ridleyi, Coelops robinsoni, Rhinolophus sedulus, Myotis ridleyi, Nycteris tragata). While abundant and common species are easier to study due to their widerange distribution, future research should focus more on threatened, data deficient and strict forest specialists which are most at threat from intensive deforestation to assess their conservation status. Such improved knowledge on each bat species needs to be generated to ensure the effectiveness and efficiency of our bat conservation initiatives. Bat communities should be monitored regularly to determine whether there is evidence of distributional shifts in relation to environmental change which will need to be accounted for ongoing conservation efforts.

\section{ACKNOWLEDGEMENTS}

We would like to acknowledge the ASTS scholarship and Short Term Grant (304/PJJAUH/6313060) from Universiti Sains Malaysia, research grant from Bat Conservation International and University of London Central Research Fund (CRFT1J8R) awarded to L. S. Lim, and a research grant (UKMTOPDOWN-ST-08-FRGS00032010) awarded to A. Zubaid. The study was conducted under the permission of the Economic Planning Unit of Malaysia (EPU), the Forestry Department of Peninsular Malaysia and the Department of Wildlife and National Parks (DWNP). We would like to thank those directly or indirectly involved with the fieldworks: Roslan Yusof, Guan Eng Tan, Hasri, Milla Loumbar, Cheng Min Wong, Ching Fong Lau, Hao-Chih Kuo, Hong Diem Vo, Mr Man, Uncle Lah, Mr and Mrs Siow Kok Wai. Finally, we appreciate the valuable input from the editor and the reviewers to significantly improve on the quality of this manuscript.

Special acknowledgement to the late Mr Mohd Yusof Ahmad from Universiti Kebangsaan Malaysia, who helped the first author in most of the challenging field sites, but unfortunately has since passed away.

\section{REFERENCES}

ANON. (1900). Mammals of Siam and the Malay Peninsula. P Zool Soc Lond, 69(3): 341-428. https://doi. org/10.1111/j.1096-3642.1890.tb01722.x

AZIZ, S.A., CLEMENTS, G.R., MCCONKEY, K.R., SRITONGCHUAY, T., PATHIL, S., ABU YAZID, M.N.H., CAMPOS-ARCEIZ, A., FORGET, P.-M., \& BUMRUNGSRI, S. (2017). Pollination by the locally endangered island flying fox (Pteropus hypomelanus) enhances fruit production of the economically important durian (Durio zibethinus). Ecology and Evolution, 7(21):8670-8684. https://doi.org/10.1002/ece3.3213

CHAIYARAT, R., BOONMA, W. \& KOEDRITH, P. (2019). The role of pteropodid bats in pollination of durian (Durio zibethinus) in managed orchards in suburban habitat of Thailand. Urban Ecosyst, 1-10. https://doi.org/10.1007/ s11252-019-00919-w

CHAN, K. W., LIM, K. K. P. \& LEONG, T. M. (2009). The Javan pipistrelle, Pipistrellus javanicus (Mammalia: Chiroptera: Vespertilionidae) in Singapore. Nature in Singapore, 2: 323-327.

CHASEN, F. N. (1935). A handlist of Malaysian mammals (A systematic list of the mammals of the Malay Peninsula, Sumatra, Borneo and Java, including the adjacent small islands). Bull. Raffles Mus., 15: 1-209. https://doi. org/10.5962/bhl.title.119907

CHASEN, F. N. (1936). New and noteworthy bats from the Malay Peninsula. Bull. Raffles Mus., 12: 133-134.

CINCOTTA, R. P., WISNEWSKI, J. \& ENGELMAN, R. (2000). Human population in the biodiversity hotspots. Nature, 404(6781): 990-992. https://doi.org/10.1038/35010105

CORBET, G. B. \& HILL, J. E. (1992). Mammals of the Indomalayan region: a systematic review. Oxford University Press. Oxford, United Kingdom, 496 pp.

EVANS, K. L. (2010). Individual species and urbanization. In: K. Gaston, Urban ecology. ed.: Ecological Reviews, Cambridge University Press. Cambridge, United Kingdom. p.53-87. https://doi.org/10.1017/ CB09780511778483.005

FAO. (2015, April 16). Forest cover in Malaysia. www. globalforestwatch.org

FRANCIS, C. M. (2008). A field guide to the mammals of South-east Asia. New Holland Publishers. London, United Kingdom, $392 \mathrm{pp}$.

FUJITA, M. S. \& TUTTLE, M. D. (1991). Flying foxes (Chiroptera: Pteropodidae): threatened animals of key ecological importance. Conservation Biology, 5(4): 455-463. https://doi.org/10.1111/j.1523-1739.1991.tb00352.x

GLOBAL FOREST WATCH. (2019). Interactive map-Malaysia, primary forest 2001. https://www.globalforestwatch. org/map 
GOULD, E. (1978a). Foraging behavior of Malaysian nectarfeeding bats. Biotropica, 10(3): 184-193. https://doi. org/10.2307/2387904

GOULD, E. (1978b). Rediscovery of Hipposideros ridleyi and seasonal reproduction in Malaysian bats. Biotropica, 10(1): 30-32. https://doi.org/10.2307/2388101

HANSEN, M .C., POTAPOV, P. V., MOORE, R., HANCHER, M., TURUBANOVA, S. A., TYUKAVINA, A., THAU, D., STEHMAN, S. V., GOETZ, S. J., LOVELAND, T. R. et al. (2013, April 16). Tree cover loss and gain area Hansen/UMD/ Google/USGS/NASA. University of Maryland, Google, USGS, and NASA. www.globalforestwatch.org

HELLER, K. G. \& VOLLETH, M. (1995). Community structure and evolution of insectivorous bats in the Palaeotropics and Neotropics. Journal of Tropical Ecology, 11(3): 429442. https://doi.org/10.1017/S0266467400008907

HODGKISON, R., BALDING, S. T., ZUBAID, A. \& KUNZ, T. H. (2003). Fruit Bats (Chiroptera: Pteropodidae) as seed dispersers and pollinators in a lowland Malaysian rain forest. Biotropica, 35(4): 491-502. https://doi. org/10.1111/j.1744-7429.2003.tb00606.x

HODGKISON, R., BALDING, S. T., ZUBAID, A. \& KUNZ, T. H. (2004). Habitat structure, wing morphology, and vertical stratification of Malaysian fruit bats (Megachiroptera: Pteropodidae). Journal of Tropical Ecology, 20(6): 667673. https://doi.org/10.1017/S0266467404001737

KEENAN, R. J., REAMS, G. A., ACHARD, F., DE FREITAS, J. V., GRAINGER, A. \& LINDQUIST, E. (2015). Dynamics of global forest area: results from the FAO Global Forest Resources Assessment 2015. For. Ecol. Manag., 352: 9-20. https:// doi.org/10.1016/j.foreco.2015.06.014

KINGSTON, T., FRANCIS, C. M., AKBAR, Z. \&, KUNZ, T.H. (2003). Species richness in an insectivorous bat assemblage from Malaysia. Journal of Tropical Ecology, 19(1): 67-79. https://doi.org/10.1017/S0266467403003080

KINGSTON, T., LIM, B. L. \& AKBAR, Z. (2006). Bats of Krau Wildlife Reserve. Penerbit Universiti Kebangsaan Malaysia. Bangi, Central Africa Republic, 145 pp.

KINGSTON, T., JULIANA, S., NURUL-AIN, E., HASHIM, R. \& ZUBAID, A. (2012). The Malaysian bat conservation research unit: from a national model to an international network. Malaysian Applied Biology, 41(2): 1-10.

KUNZ, T. H., BRAUN DE TORREZ, E., BAUER, D., LOBOVA, T. \& FLEMING, T.H. (2011). Ecosystem services provided by bats. Annals of the New York Academy of Sciences, 1223(1): 1-38. https://doi.org/10.1111/j.17496632.2011.06004.x

LANE, D. J. W., KINGSTON, T. \& LEE, B. P. Y. -H. (2006). Dramatic decline in bat species richness in Singapore, with implications for Southeast Asia. Biological Conservation, 131(4): $\quad$ 584-593. https://doi.org/10.1016/j. biocon.2006.03.005
LEONG, T. M. \& LIM, K. K. P. (2009). Noteworthy microchiropteran records from the Bukit Timah and Central Catchment Nature Reserves, Singapore. Nature in Singapore, 2: 83-90.

LIM, B. L. \& MUUL, I. (1978). Small mammals. In: Kinabalu Summit of Borneo. Sabah Society \& WWF Malaysia. Kota Kinabalu, Sabah, Malaysia, p.403-407.

LIM, L. -S., MOHD-ADNAN, A., ZUBAID, A., STRUEBIG, M. J. \& ROSSITER, S. J. (2014). Diversity of Malaysian insectivorous bat assemblages revisited. Journal of Tropical Ecology, 30(2): 111-121. https://doi. org/10.1017/S0266467413000874

LIM, V. -C., RAMLI, R., BHASSU, S. \& WILSON, J. -J. (2017). A checklist of the bats of Peninsular Malaysia and progress towards a DNA barcode reference library. PLOS ONE, 12(7): e0179555. https://doi.org/10.1371/journal. pone.0179555

MANCINA, C. A., GARCÍA-RIVERA, L., \& MILLER, B. W. (2012). Wing morphology, echolocation, and resource partitioning in syntopic Cuban mormoopid bats. Journal of Mammalogy, 93(5): 1308-1317. https://doi. org/10.1644/11-MAMM-A-331.1

MARSHALL, A. G. (1983). Bats, flowers and fruit: evolutionary relationships in the Old World. Biological Journal of the Linnean Society, 20(1): 115-135. https://doi. org/10.1111/j.1095-8312.1983.tb01593.x

MEDWAY, L. \& MARSHALL, A.G. (1972). Roosting associations of flat-headed bats, Tylonycteris species (Chiroptera: Vespertilionidae) in Malaysia. Journal of Zoology, 168(4): 463-482.https://doi.org/10.1111/j.1469-7998.1972. tb01362.x

MEYER, C. F. J., STRUEBIG, M. J. \& WILLIG, M. R. (2016). Responses of tropical bats to habitat fragmentation, logging, and deforestation. In: Bats in the Anthropocene - Conservation of bats in a changing world. ed.: Springer Cham. eBook, p.63-103. https://doi.org/10.1007/978-3319-25220-9_4

MIALHE, E. \& LANDAU, I. (1977). Description of Hepatocystis bainae n.sp, parasite of Hipposideros galeritus (Cantor), Microchiroptera, in Malaysia. Ann parasite hum comp, 52(4): 385-390.

MORNI, M. A., TAHIR, N. F. D. A., ROSLI, Q. S., DEE, J. M., AZHAR, I., ROSLAN, A., ZAHIDIN, M. A., ABDULLAH, M. T. \& FAISAL, A. A. K. (2016). New record of Rhinolophus chiewkweeae (Chiroptera: Rhinolophidae) from the east coast of Peninsular Malaysia with new information on their echolocation calls, genetics and their taxonomy. The Raffles Bulletin of Zoology, 64: 242-249.

MUUL, I. \& LIM, B. L. (1971). New locality records for some mammals of West Malaysia. Journal of Mammalogy, 52(2): 430-437. https://doi.org/10.2307/1378686 
MYERS, N., MITTERMELER, R. A., MITTERMELER, C. G., FONSECA, G. A. B. \& KENT, J., (2000). Biodiversity hotspots for conservation priorities. Nature, 403: 853858. https://doi.org/10.1038/35002501

NORBERG, U. M. \& RAYNER, J. M. (1987). Ecological morphology and flight in bats (Mammalia; Chiroptera): wing adaptations, flight performance, foraging strategy and echolocation. Phil. Trans. R. Soc. Lond. B., 316(1179): 335-427. https://doi.org/10.1098/rstb.1987.0030

ROSSITER, S. J., ZUBAID, A., MOHD-ADNAN, A., STRUEBIG, M. J., KUNZ, T. H., GOPAL, S., PETIT, E. J. \& KINGSTON, T. (2012). Social organization and genetic structure: insights from codistributed bat populations. Molecular Ecology, 21(3): 647-661. https://doi.org/10.1111/j.1365294X.2011.05391.x

SHEHERAZADE, S., OBER, H. K. \& TSANG, S. M. (2019). Contributions of bats to the local economy through durian pollination in Sulawesi, Indonesia. Biotropica, 51(6): 913-922. https://doi.org/10.1111/btp.12712

SHILTON, L. A., ALTRINGHAM, J. D., COMPTON, S. G. \& WHITTAKER, R. J. (1999). Old World fruit bats can be longdistance seed dispersers through extended retention of viable seeds in the gut. Proc. R. Soc. Lond. B., 266(1416): 219-223. https://doi.org/10.1098\%2Frspb.1999.0625

STILLER, D. (1976). Report of a new bat fly of genus Ascodipterona adensamer, 1896 (Diptera: Streblidae) parasitic on Hipposideros diadema (Geoffroy) in Malaysia. Journal of Medical Entomology, 13(3): 374375. https://doi.org/10.1093/jmedent\%2F13.3.374

STOCKWELL, E. F. (2001). Morphology and flight manoeuvrability in New World leaf-nosed bats (Chiroptera: Phyllostomidae). Journal of Zoology, 254(4): 505-514.https://doi.org/10.1017/S0952836901001005

STRUEBIG, M. J., KINGSTON, T., ZUBAID, A., MOHDADNAN, A. \& ROSSITER, S. J. (2008). Conservation value of forest fragments to Palaeotropical bats. Biological Conservation, 141(8): 2112-2126. https://doi. org/10.1016/j.biocon.2008.06.009
STRUEBIG, M. J., KINGSTON, T., ZUBAID, A., LE COMBER, S. C., MOHD-ADNAN, A., TURNER, A., KELLY, J., BOZEK, M. \& ROSSITER, S. J. (2009). Conservation importance of limestone karst outcrops for Palaeotropical bats in a fragmented landscape. Biological Conservation, 142(10): 2089-2096. https://doi.org/10.1016/j. biocon.2009.04.005

STRUEBIG, M. J., WILTING, A., GAVEAU, D.L.A., MEIJAARD, E., SMITH, R. J., THE BORNEO MAMMAL DISTRIBUTION CONSORTIUM, FISCHER, M., METCALFE, K., KRAMERSCHADT, S., et al. (2015). Targeted conservation to safeguard a biodiversity hotspot from climate and landcover change. Current Biology, 25(3): 372-378. https:// doi.org/10.1016/j.cub.2014.11.067

TAN-SOO, J., ADNAN, N., AHMAD, I., PATTANAYAK, S. K. \& VINCENT, J. R. (2016). Econometric evidence on forest ecosystem services: deforestation and flooding in Malaysia. Environmental and Resource Economics, 63: 25-44. https://doi.org/10.1007/s10640-014-9834-4

WALLACE, A. R. (1860). On the zoological geography of the Malay Archipelago. Zoological Journal of the Linnean Society, 4(16): 172-184. https://doi. org/10.1111/j.1096-3642.1860.tb00090.x

WANGER, T. C., DARRAS, K., BUMRUNGSRI, S., TSCHARNTKE, T. \& KLEIN, A. -M. (2014). Bat pest control contributes to food security in Thailand. Biological Conservation, 171: 220-223. https://doi.org/10.1016/j.biocon.2014.01.030

WILLIAMS, J. (2013). Humans and biodiversity: population and demographic trends in the hotspots. Popul Environ, 34: 510-523. https://doi.org/10.1007/s11111-012-01753

YOSHIYUKI, M. \& LIAT, L. B. (2005). A new Horseshoe Bat, Rhinolophus Chiewkweeae (Chiroptera, Rhinolophidae), from Malaysia. Bulletin of the National Science Museum, 31(1): 29-36. 